\title{
Initial Crown Diameter of Strawberry Bare-root Transplants Affects Early and Total Fruit Yield
}

\author{
Emmanuel A. Torres-Quezada ${ }^{1,2}$, Lincoln Zotarelli ${ }^{2,4}$, \\ Vance M. Whitaker ${ }^{1,2}$, Bielinski M. Santos ${ }^{2,3}$, and \\ Ixchel Hernandez-Ochoa ${ }^{1}$
}

\begin{abstract}
AdDitionAl INDEX wORDs. canopy diameter, Fragaria $\times$ ananassa, plant size, strawberry cultivars

SUMMARY. The standard strawberry (Fragaria $\times$ ananassa) production system in Florida uses bare-root transplants with three to five leaves; however, commercial transplants are typically variable in size. The objective of this experiment was to study the effects of transplant crown diameter on the subsequent performance of three short-day strawberry cultivars under central Florida conditions. Trials were carried out during the 2012-13 and 2013-14 growing seasons with six treatments resulting from the combination of three cultivars and two crown diameter categories. Transplants of 'Florida Radiance', 'Strawberry Festival', and WinterStar ${ }^{\mathrm{TM}}$ were sorted into two initial crown diameter size ranges: $<10 \mathrm{~mm}$ and $>10 \mathrm{~mm}$. Treatments were established in a split-plot design with cultivars as the main plot and four replications. Dry plant biomass was collected at 6 weeks after transplant (WAT). Canopy diameter and crown diameter were measured at 6 and $18 \mathrm{WAT}$ and fruit harvest started at $8 \mathrm{WAT}$. There were no interactions between cultivar and initial crown diameter for any of the measured variables. For early yield, larger crowns led to $46 \%\left(3.5 \mathrm{Mg} \cdot \mathrm{ha}^{-1}\right)$ and $38 \%\left(3.9 \mathrm{Mg} \cdot \mathrm{ha}^{-1}\right)$ higher early yield than smaller crowns in 2012-13 and 2013-14, respectively. Crown diameters $>10 \mathrm{~mm}$ also resulted in $18 \%\left(23.5 \mathrm{Mg} \cdot \mathrm{ha}^{-1}\right)$ and $27 \%\left(17.4 \mathrm{Mg} \cdot \mathrm{ha}^{-1}\right)$ higher total yields in 2012-13 and 2013-14, respectively.
\end{abstract}

$\mathrm{C}$ alifornia and Florida are the two leading producers of cultivated strawberries in the United States [U.S. Department of Agriculture (USDA), 2012]. Florida production in the winter months represents $16 \%$ of the national total production (Mossler, 2010). The Florida farm gate crop value was $\approx \$ 333$ million, from a crop grown on $\approx 10,600$ acres in 2013 (USDA, 2014a). Although strawberry is the most valuable crop per unit land area in Florida, the industry has faced increasing market competition. Mexico is the biggest competitor for Florida's strawberry market window, with more than 229,000 tons imported to the United States in 2011 (Wu et al., 2012). Increased imports have contributed to the decrease in the seasonal average price, which fell from $\$ 1.87$ to $\$ 1.10$ per pound of strawberries between 2010 and 2012

${ }^{1}$ Gulf Coast Research and Education Center, Institute of Food and Agricultural Sciences (IFAS), University of Florida, 14625 CR 672, Wimauma, FL 33598

${ }^{2}$ Horticultural Sciences Department, IFAS, University of Florida, Gainesville, FL 32611

${ }^{3}$ Former Associate Professor.

${ }^{4}$ Corresponding author. E-mail: lzota@ufl.edu.
(USDA, 2012). To achieve profitability in a more competitive market, it is necessary to take advantage of specific time periods that are most likely to coincide with high market prices. The highest strawberry prices occur between late November and early December, which is when Mexico has not yet reached full production (Tanino and Wang, 2008; Wu et al., 2012). This highprice window overlaps with the first weeks of production in Florida, which makes early season yield an important target for growers (Bish and Cantliffe, 2002; Gilreath et al., 2006).
In short-day strawberry production, high quality transplants are essential for early fruit yield. The production system in Florida uses bare-root transplants, with three to four intact leaves (Bish et al., 2002), which are established by overhead irrigation during daylight hours for up to $10 \mathrm{~d}$. Bare-root transplants for Florida are usually grown in southern Canada and in high-elevation regions of North Carolina and California during the summer months, and are then dug and shipped in refrigerated trucks in late September and early October (Bish and Cantliffe, 2003; Hochmuth et al., 2006; Hokanson et al., 2004). Bare-root transplants are affordable to growers, but usually vary in crown size and overall quality (Bish et al., 2000). Once bare-root transplants are shipped, a high proportion of roots become unable to take up water and nutrients, due to mechanical injury from field digging, accentuating stress, shortly after transplanting (Cocco et al., 2011). Carbohydrate accumulation and mobilization have an important role in plant development, and crown starch reserves represent a crucial source of carbohydrates for plant development (Macias-Rodriguez et al., 2002). A wide variation in crown sizes directly affects plant vigor and stand uniformity. It has been hypothesized that larger transplants will result in higher strawberry yield (Bish and Cantliffe, 2003; Menzel and Smith, $2011,2012)$. However, there are contradictory results as to whether wider crown diameters result in higher yield, especially when factors such as cultivar and seasonal conditions are taken into account (Cocco et al., 2011; Johnson et al., 2008).

Cocco et al. (2011) compared three classifications of bare-root transplants with crown diameters

\begin{tabular}{llll}
\hline $\begin{array}{l}\text { Units } \\
\text { To convert U.S. to SI, } \\
\text { multiply by }\end{array}$ & U.S. unit & SI unit & $\begin{array}{l}\text { To convert SI to U.S., } \\
\text { multiply by }\end{array}$ \\
\hline 0.4047 & acre(s) & $\mathrm{ha}$ & 2.4711 \\
0.3048 & $\mathrm{ft}$ & $\mathrm{m}$ & 3.2808 \\
3.7854 & gal & $\mathrm{L}$ & 0.2642 \\
2.54 & inch(es) & $\mathrm{cm}$ & 0.3937 \\
25.4 & inch(es) & $\mathrm{mm}$ & 0.0394 \\
0.4536 & $\mathrm{lb}$ & $\mathrm{kg}$ & 2.2046 \\
1.1209 & $\mathrm{lb} / \mathrm{acre}$ & $\mathrm{kg} \cdot \mathrm{ha}^{-1}$ & 0.8922 \\
0.0254 & mil & $\mathrm{mm}$ & 39.3701 \\
28.3495 & $\mathrm{oz}$ & $\mathrm{g}$ & 0.0353 \\
0.9072 & ton $(\mathrm{s})$ & $\mathrm{Mg}$ & 1.1023 \\
2.2417 & ton $(\mathrm{s}) / \mathrm{acre}$ & $\mathrm{Mg} \cdot \mathrm{ha}^{-1}$ & 0.4461 \\
$\left({ }^{\circ} \mathrm{F}-32\right) \div 1.8$ & ${ }^{\circ} \mathrm{F}$ & ${ }^{\circ} \mathrm{C}$ & $\left({ }^{\circ} \mathrm{C} \times 1.8\right)+32$ \\
& & &
\end{tabular}


ranging from 3 to $5 \mathrm{~mm}, 5.1$ to 8 $\mathrm{mm}$, and $>8.1 \mathrm{~mm}$. The authors concluded that bare-root transplants with crowns between 5.1 and $8 \mathrm{~mm}$ and $>8 \mathrm{~mm}$ resulted in similar yield. However, plants with crowns $<5 \mathrm{~mm}$ resulted in $15 \%$ lower yield compared with those $5.1 \mathrm{~mm}$ and higher. In addition, Johnson et al. (2008) evaluated 'Chandler' and 'Camarosa' bare-root transplants planted in an annual hill system with four classifications of crown diameter between 6.5 and $17.3 \mathrm{~mm}$. They found a positive linear relationship between 'Chandler' early yield and crown diameter. However, 'Camarosa' did not show similar results, suggesting a possible cultivar-dependent effect of crown diameter. Crown diameter effects have been evaluated in Florida for 'Sweet Charlie' bare-root transplants. As with 'Camarosa', no consistent relationship between crown sizes and early yield were found (Stapleton et al., 2001). However, experiments with 'Strawberry Festival' in Queensland, Australia, showed that plants with crowns of $12 \mathrm{~mm}$ diameter resulted in $17 \%$ higher yield than 7-mm-diameter crowns (Menzel and Smith, 2011). If the effect of crown diameter is cultivar-dependent, it would be informative to evaluate the possible crown diameter by cultivar interaction for cultivars currently used by Florida growers. Therefore, the objective of this experiment was to study the effects of transplant crown diameter on the performance of three strawberry cultivars under Florida conditions.

\section{Materials and methods}

Field trials were conducted during the 2012 and 2013 seasons at the Gulf Coast Research and Education Center of the University of Florida, located in Wimauma, FL (lat. $27^{\circ} 75^{\prime} \mathrm{N}$, long. $82^{\circ} 22^{\prime} \mathrm{E}$ ). The soil at the experimental site is classified as a Myakka fine sand, siliceous hyperthermic Oxyaquic Alorthod with $<1.5 \%$ organic matter and a $\mathrm{pH}$ of 6.6. Soil $\mathrm{pH}$ was measured with a $\mathrm{pH}$ meter (Pinnacle series M530P; SI Analytics, Mainz, Germany) by placing a glass electrode (UX-5931-24; Cole-Parmer, Vernon Hills, IL) in a mixture of soil and deionized water $(\mathrm{l}: \mathrm{l} \mathrm{v} / \mathrm{v})$. Before planting, the soil was tilled twice to an approximate depth of 8 inches (BP421 double disk; Kenco Manufacturing, Atoka, OK). In late August of both seasons, pressed beds were formed that were 27 inches wide at the base, 24 inches wide at the top, and 10 inches high, spaced $4 \mathrm{ft}$ apart on center. During pressing, beds were fumigated with 1,3-dichloropropene $(63.4 \%)+$ chloropicrin $(34.7 \%)$ at a rate of $250 \mathrm{lb} /$ acre (Telone C-35; Dow AgroScience, Indianapolis, IN). Immediately after fumigation, beds were covered with high-density black polyethylene mulch film (1 mil thick; Intergro Company, Clearwater, FL). At the same time, one drip tape line $\left(0.5 \mathrm{~L} \cdot \mathrm{h}^{-1}\right.$ per emitter, 12 inches between emitters; Rivulis, Gvat, Israel) was applied to the top center of the bed, directly under the polyethylene film. Strawberry bare-root transplants were planted on 9 Oct. 2012 and 7 Oct. 2013. The six treatments included a combination of three cultivars (Strawberry Festival, FL Radiance, and WinterStar ${ }^{\mathrm{TM}}$ ) and two crown diameter categories $(<10 \mathrm{~mm}$ and $>10 \mathrm{~mm}$ ) replicated four times, in a split-plot design, with cultivars as the main plot and crown size as the split-plot. Experimental units were 18 $\mathrm{ft}$ long (30 plants/plot). Immediately after planting, overhead sprinkler irrigation $\left(1021 \mathrm{~L} \cdot \mathrm{h}^{-1}\right.$ per sprinkler) was applied for $10 \mathrm{~d}$ during daylight hours for establishment. After establishment, transplants were drip irrigated twice per day at 0800 and 1300 HR. Irrigation cycles were adjusted according to the average reference evapotranspiration for west central Florida from October to March and adjusted for the crop growing stages (Simonne and Dukes, 2009) according to standard commercial practice. Daily fertilizer applications started 1 WAT through the drip lines using a hydraulic injector (Dosatron International, Clearwater, FL) to pump concentrated stock solution into the irrigation water, using a dilution rate of $1: 50(\mathrm{v} / \mathrm{v})$.

Essential nutrients were supplied following statewide recommendations and initial soil test analysis (Santos et al., 2013). Plots received $\approx 150$ $\mathrm{kg} \cdot \mathrm{ha}^{-1}$ of nitrogen $(\mathrm{N})$ through the irrigation system during a 5-monthseason via a daily injection during the second daily irrigation cycle. Plots were fertigated using a solution with nutrient levels of $6 \% \mathrm{~N}, 2 \%$ phosphorus, $8 \%$ potassium, $2 \%$ calcium, $\quad 0.4 \%$ magnesium, $0.02 \%$ boron, $0.04 \%$ manganese, and 0.02\% zinc (Dyna Fo 6-2$8 \mathrm{MlM}$ w/Merge; Chemical Dynamics, Plant City, FL). Pest and disease scouting was conducted weekly. Throughout both seasons, two spotted mites (Tetranychus urticae), armyworms (Spodoptera eridania), and western flower thrips (Frankliniella bispinosa) were detected. Disease levels were considered minimal, though some plants were affected by angular leaf spot (Xanthomonas fragariae), botrytis (Botrytis cinerea), and anthracnose fruit rot (Colletotrichum acutatum). Disease and pest management was conducted according to commercial standards (Santos et al., 2013).

Bare-root transplants (Crown Nursery, Red Bluff, CA) were set 15 inches apart in double rows with 10 inches between rows within the beds. During the nursery stage in 2012, plants received $\approx 206 \mathrm{~h}$ of chilling (determined as hours at temperature between $\mathrm{l}$ and $7{ }^{\circ} \mathrm{C}$ ), data were not available for 2013. 'Florida Radiance', 'Strawberry Festival', accounted for $70 \%$ of commercial acreage at the time of the experiment and 'FL 05-107' strawberry (marketed as and referred to hereafter as WinterStar ${ }^{\top \mathrm{TM}}$ ) was steadily increasing in acreage (Whitaker et al., 2011); the three cultivars were selected for both growing seasons of experimentation. Bare-root transplants were manually sorted in two groups: crown diameters $<10 \mathrm{~mm}$ and $>10 \mathrm{~mm}$ based on the report of Menzel and Smith (2012) that between $40 \%$ and $48 \%$ of bare-root shipments had crowns with a diameter $<10 \mathrm{~mm}$. Bare-root crowns were measured individually with a digital caliper (Mitutoyo 500-196-20; Mitutoyo America, Aurora, IL), and classified as $>10 \mathrm{~mm}$ or $<10 \mathrm{~mm}$, though crowns $4 \mathrm{~mm}$ or less in diameter were discarded. Selected transplants had three to five leaves with no visible signs of mechanical damage or disease incidence.

Strawberry plant survival was assessed $10 \mathrm{~d}$ after planting. A representative sample was collected for dry shoot biomass quantification 6 WAT, using 10 plants from each plot. Plants for shoot biomass measurements were extracted from the beds and washed with water to remove soil, dried at $80{ }^{\circ} \mathrm{C}$ for $5 \mathrm{~d}$, and then weighed. 
Canopy diameter and crown diameter were measured at 6 and 18 WAT using five randomly selected plants per plot. The same five plants were used during both sampling dates. Crown diameter was measured at the base of the plant, between the plant canopy and the surface of the plastic mulch. Canopy diameter was assessed by measuring the distance between the two outermost contrary leaves. Early and total marketable fruit weight and number were collected from each plot (20 plants/ plot) starting at 9 WAT in 2012 and 8 WAT in 2013. Early marketable yield (grams) was defined as the $\mathrm{cu}^{-}$ mulative marketable weight of the first five harvests, whereas total marketable yield consisted of 20 harvests during each season. Fruit were harvested on Mondays and Thursdays of each week between 10 Dec. 2012 and 28 Feb. 2013; and 2 Dec. 2013 and $20 \mathrm{Feb}$. 2014. A marketable fruit was defined as a fruit of at least $10 \mathrm{~g}$, without visible blemishes, and at least $75 \%$ external red color. Average fruit weight was determined by dividing the marketable fruit weight of each treatment by its corresponding fruit number only in 2013. The main effect of growing season, cultivar and crown diameter, and their interactions were considered fixed and were examined for significance $(P<0.05)$ using a general linear model (Statistix 9 Analytical Software, Tallahassee, FL). Treatment means were compared using Fisher's protected least significance difference test $(P<0.05)$.

\section{Results and discussion}

On average across the experiment, total yield from 2012-13 was $22.1 \mathrm{Mg} \cdot \mathrm{ha}^{-1}$, whereas in $2013-14$ it was $15.1 \mathrm{Mg} \cdot \mathrm{ha}^{-1}$. This was most likely related to the higher temperatures registered in Oct., Nov., and Dec. 2013-14 (164 h above $26^{\circ} \mathrm{C}$ ), compared with the 2012-13 season $\left(310 \mathrm{~h}\right.$ above $26^{\circ} \mathrm{C}$ ) (Fig. 1) (Florida Automated Weather Network, 2014). Also, higher rainfall occurred in 2013-14 (116 mm) than in 2012-13 $(94 \mathrm{~mm})$, between December and February (Fig. 1), when most fruit were harvested. The higher temperatures of the 2013-14 season likely contributed to a delay and reduction in flowering, and higher rainfall could have contributed to a higher percentage of
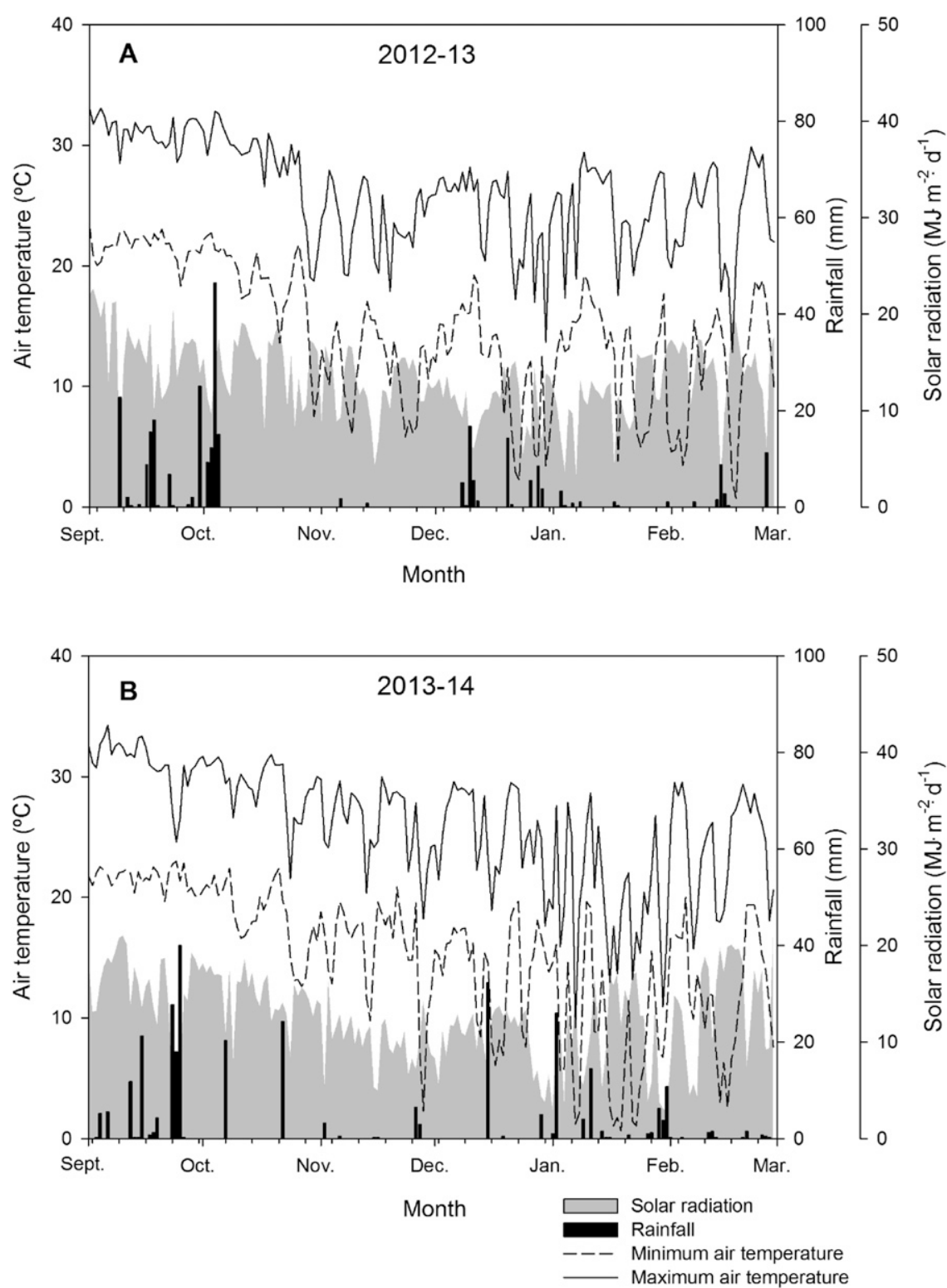

Fig. 1. Minimum and maximum air temperature, solar radiation, and rainfall at the experimental site, Balm, FL, in the (A) 2012-13 and (B) 2013-14 strawberry growing season; $\left(1.8 \times{ }^{\circ} \mathrm{C}\right)+32={ }^{\circ} \mathrm{F}, 1 \mathrm{MJ} \cdot \mathrm{m}^{-2} \cdot \mathrm{d}^{-1}=1.0749 \mathrm{~W} / \mathrm{ft}^{2}, 1 \mathrm{~mm}=$ 0.0394 inch.

water damage and fruit rot fruit (Yang et al., 1990), as fungal spores can be disperses by free water and rain-drop splash (Jarvis, 1962).

All plants were successfully established during both seasons, showing no effect of the treatments on plant survival. There were no interactions between cultivar and initial crown diameter for any of the measured variables (Tables 1-4). Growing season by treatment interactions for dry plant biomass, canopy diameter, and crown diameter were not significant. Therefore data for these variables were averaged over both seasons. There was no interaction between cultivar and crown diameter treatments for dry plant biomass. At 6 WAT, dry plant biomass ranged from 18 to $25 \mathrm{~g}$ with no differences by crown size or cultivar (Table 1 ). For canopy diameter, there was no effect of cultivar at 6 and 18 WAT, with means of 21 and $37 \mathrm{~cm}$, respectively. Canopy diameter was higher at 6 WAT for plants with wider initial crown diameters. However, by week 18, both transplant size categories had a mean canopy diameter of 38 $\mathrm{cm}$. Cultivar had no effect on crown diameter at 6 WAT, but by week 18, 'Strawberry Festival' crowns were wider $(60 \mathrm{~mm})$ compared with those 
of 'Florida Radiance' and WinterStar ${ }^{\mathrm{TM}}$, which averaged $52 \mathrm{~mm}$.

There was a significant interaction between season and initial crown diameter for early and total marketable fruit weight, thus data were analyzed by season (Table 2 ). In both seasons, cultivars showed no difference in early yield. However, at 15 WAT 'Florida Radiance' and 'Strawberry Festival' resulted in higher yields than WinterStarT ${ }^{\mathrm{TM}}$ in both seasons (Table 2). In 2012-13 at 17 WAT, yield of 'Strawberry Festival' was $15.1 \mathrm{Mg} \cdot \mathrm{ha}^{-1}$ and was higher than 'Florida Radiance' and WinterStar ${ }^{\mathrm{TM}}$. In 2013-14, 'Strawberry Festival' and 'Florida Radiance' resulted in higher yields than WinterStar ${ }^{\mathrm{TM}}$ at 15 and 17 WAT. For total marketable fruit weight, there was no difference among cultivars in 2012-13 growing season. However, 'Florida Radiance' and WinterStar ${ }^{\mathrm{TM}}$ had higher total yields in 2013-14 relative to 'Strawberry Festival'.

Initial crown diameter treatments gave consistent results in both seasons, with wider crowns resulting in higher yields for all cultivars. For early yield, larger crowns led to $46 \%$ $\left(3.5 \mathrm{Mg} \cdot \mathrm{ha}^{-1}\right.$ ) and $38 \%\left(3.9 \mathrm{Mg} \cdot \mathrm{ha}^{-1}\right)$ higher early yield than smaller crowns in 2012-13 and 2013-14, respectively (Table 2). Crown diameters $>10 \mathrm{~mm}$ also resulted in $18 \%(23.5$ $\mathrm{Mg} \cdot \mathrm{ha}^{-1}$ ) and 27\% (17.4 Mg.ha $\left.{ }^{-1}\right)$ higher total yields in 2012-13 and 2013-14, respectively. Further, the effect was not cultivar dependent, as there was no interaction between crown diameter and cultivar for any of the measured variables in either season (Tables 1-4).

Strawberry crowns represent an important reservoir for carbohydrates
(Macias-Rodriguez et al., 2002). Even though crowns do not comprise the highest biomass percentage of the plant during fruiting, it is estimated that $75 \%$ of the required carbohydrates for the first $7 \mathrm{~d}$ of fruit growth comes from carbohydrate reserves, which includes roots and crowns (Darnell and Martin, 1988). For bare-root transplants, crowns represent a carbohydrates source for developing roots and leaves during the establishment process. However, depending on the weather conditions and water status in the soil during establishment, the impact of crown size might be more or less important. Water and nutrient uptake from the roots are minimal during the establishment stage hence future dry weight gain is mainly dependent on the crowns for carbohydrates (Cocco et al., 2011). Our results indicate that

Table 1. Effects of cultivar and bare-root transplant crown diameter on aboveground dry biomass, canopy diameter, and crown diameter of strawberry plants at 6 and 18 weeks after transplanting (WAT) at Balm, FL, in the 2012-13 and 2013-14 growing season.

\begin{tabular}{|c|c|c|c|c|c|}
\hline \multirow[b]{2}{*}{ Treatments } & \multirow{2}{*}{$\frac{\text { Dry biomass }(\mathrm{g})^{\mathrm{z}}}{6 \mathrm{WAT}^{\mathrm{y}}}$} & \multicolumn{2}{|c|}{ Canopy diam $(\mathrm{cm})^{\mathrm{z}}$} & \multicolumn{2}{|c|}{ Crown diam $(\mathrm{mm})^{\mathrm{z}}$} \\
\hline & & 6 WAT & $18 \mathrm{WAT}$ & 6 WAT & 18 WAT \\
\hline \multicolumn{6}{|l|}{ Cultivar } \\
\hline WinterStar ${ }^{\mathrm{TM}}$ & 18 & 21 & 36 & 18 & $52 \mathrm{~b}$ \\
\hline Strawberry Festival & 25 & 22 & 39 & 19 & $60 \mathrm{a}$ \\
\hline Significance $^{\mathrm{x}}$ & NS & NS & NS & NS & * \\
\hline$>10 \mathrm{~mm}$ & 24 & 22 & 38 & 20 & 54 \\
\hline Significance & NS & * & NS & * & NS \\
\hline
\end{tabular}

${ }^{\mathrm{z}} \mathrm{lg}=0.0353 \mathrm{oz}, \mathrm{l} \mathrm{cm}=0.3937$ inch, $1 \mathrm{~mm}=0.0394$ inch.

yWT

'Values followed by the different letters (columns) indicate that the means of cultivars are significantly different $(P \leq 0.05)$ according to Fisher's-protected least significant difference test within WAT; Ns, * Nonsignificant or significant at $P \leq 0.05$

wInitial crown diameter at transplanting.

Table 2. Effect of initial crown diameter and cultivar on strawberry cumulative early and total fruit yield at $12,15,17$, and 20 weeks after transplanting (WAT), at Balm, FL, in the 2012-13 and 2013-14 growing season.

\begin{tabular}{|c|c|c|c|c|c|c|c|c|}
\hline \multirow[b]{3}{*}{ Treatment } & \multicolumn{4}{|c|}{ 2012-13 Season } & \multicolumn{4}{|c|}{ 2013-14 Season } \\
\hline & \multicolumn{8}{|c|}{ WAT } \\
\hline & 12 & 15 & 17 & 20 & 12 & 15 & 17 & 20 \\
\hline \multicolumn{9}{|l|}{ Cultivar } \\
\hline Florida Radiance & 2.7 & $7.7 \mathrm{a}^{\mathrm{y}}$ & $12.7 \mathrm{~b}$ & 22.3 & 3.4 & $9.9 \mathrm{a}$ & $9.8 \mathrm{a}$ & $16.3 \mathrm{a}$ \\
\hline Strawberry Festival & 2.5 & $7.6 \mathrm{a}$ & $15.1 \mathrm{a}$ & 22.3 & 3.1 & $6.7 \mathrm{a}$ & $8.8 \mathrm{a}$ & $13.2 \mathrm{~b}$ \\
\hline WinterStar ${ }^{\mathrm{TM}}$ & 2.8 & $6.0 \mathrm{~b}$ & $11.3 \mathrm{~b}$ & 21.8 & 3.1 & $4.6 \mathrm{~b}$ & $6.8 \mathrm{~b}$ & $15.9 \mathrm{a}$ \\
\hline$<10 \mathrm{~mm}^{\mathrm{x}}$ & 1.9 & 5.9 & 11.2 & 19.4 & 2.4 & 4.6 & 6.2 & 12.8 \\
\hline$>10 \mathrm{~mm}$ & 3.5 & 8.6 & 14.9 & 23.5 & 3.9 & 7.6 & 10.7 & 17.4 \\
\hline Significance & * & * & * & * & * & * & * & * \\
\hline
\end{tabular}

${ }^{\mathrm{z}} \mathrm{l} \mathrm{Mg} \cdot \mathrm{ha}^{-1}=0.4461$ ton/acre.

${ }^{y}$ Values followed by the different letters (columns) indicate that the means of cultivars are significantly different $(P \leq 0.05)$ according to Fisher's-protected least significant difference test within WAT; Ns, *Nonsignificant or significant at $P \leq 0.05$.

${ }^{\mathrm{x}}$ Initial crown diameter at transplanting; $1 \mathrm{~mm}=0.0394$ inch. 
Table 3. Effects of initial crown diameter and cultivar on strawberry average fruit yield at 12, 1517 , and 20 weeks after transplanting (WAT), at Balm, FL, in the 2012-13 growing season.

\begin{tabular}{|c|c|c|c|c|}
\hline Treatments & 12 WAT & 15 WAT & 17 WAT & 20 WAT \\
\hline \multicolumn{5}{|l|}{ Cultivar } \\
\hline Florida Radiance & $24.7 \mathrm{a}^{\mathrm{y}}$ & $24.1 \mathrm{a}$ & $24.6 \mathrm{a}$ & $25.5 \mathrm{a}$ \\
\hline Strawberry Festival & $20.7 \mathrm{~b}$ & $19.3 \mathrm{c}$ & $20.5 \mathrm{~b}$ & $20.4 \mathrm{c}$ \\
\hline WinterStar ${ }^{\mathrm{TM}}$ & $21.4 \mathrm{~b}$ & $22.2 \mathrm{~b}$ & $24.2 \mathrm{a}$ & $23.8 \mathrm{~b}$ \\
\hline Significance $^{\mathrm{y}}$ & * & * & * & * \\
\hline \multicolumn{5}{|l|}{$\begin{array}{l}\text { Initial crown } \\
\text { diameter }\end{array}$} \\
\hline$<10 \mathrm{~mm}$ & 22.4 & 21.8 & 23.3 & 23.4 \\
\hline$>10 \mathrm{~mm}$ & 22.2 & 22.0 & 22.9 & 23.1 \\
\hline Significance & NS & NS & NS & NS \\
\hline
\end{tabular}

Table 4. Effects of crown diameter and cultivar on strawberry total cumulative fruit number at $12,15,17$, and 20 weeks after transplanting (WAT), at Balm, FL, in the 2012-13 growing season.

\begin{tabular}{|c|c|c|c|c|}
\hline Treatments & 12 WAT & 15 WAT & 17 WAT & 20 WAT \\
\hline Cultivar & \multicolumn{4}{|c|}{ - fruit/ha $)^{\mathrm{z}}-\mathrm{c}$} \\
\hline Florida Radiance & 111,289 & $317,735 b^{y}$ & $515,430 \mathrm{~b}$ & $800,625 \mathrm{~b}$ \\
\hline Strawberry Festival & 118,125 & 418,633 a & $738,282 \mathrm{a}$ & $1,090,000 \mathrm{a}$ \\
\hline WinterStar ${ }^{\top M}$ & 131,797 & $267,969 \mathrm{~b}$ & $469,219 \mathrm{~b}$ & $918,750 \mathrm{~b}$ \\
\hline Significance ${ }^{\mathrm{y}}$ & NS & * & * & * \\
\hline \multicolumn{5}{|l|}{ Initial crown diameter ${ }^{x}$} \\
\hline$<10 \mathrm{~mm}$ & 84,219 & 271,797 & 487,083 & 837,266 \\
\hline$>10 \mathrm{~mm}$ & 156,589 & 397,761 & 661,537 & $1,030,000$ \\
\hline Significance & * & * & * & * \\
\hline
\end{tabular}

${ }^{\mathrm{z}} 1$ fruit/ha $=0.4047$ fruit/acre.

Values followed by the different letters (columns) indicate that the means of cultivars are significantly different $(P \leq 0.05)$ according to Fisher's-protected least significant difference test within WAT; ${ }^{\mathrm{Ns}, * N o n s i g n i f i c a n t}$ or significant at $P \leq 0.05$.

${ }^{\mathrm{x}}$ Initial crown diameter at transplanting; $1 \mathrm{~mm}=0.0394$ inch

crown size has a pronounced effect on yield under Florida conditions in both seasons under study.

Menzel and Smith (2011) evaluated the effect of strawberry transplant size in Queensland, Australia, and found similar results; plants with large crowns ranging in size from 10 to $17 \mathrm{~mm}$ resulted in $17 \%$ higher yields than plants with smaller crowns in 'Strawberry Festival'. Results were consistent for both 'Florida Radiance' and 'Strawberry Festival', where plants with wider crowns had higher yields than plants with smaller crowns (Menzel and Smith, 2012). The difference in yield was attributed to dry matter production of large plants compared with small plants. These results are similar to ours, which showed no increase in average fruit weight (Table 3 ), but did show an increase in fruit number for plants with large crowns (Table 4) in 2012. At the nursery stage, first and second order plants (first and second rooted daughter plants) develop larger crowns compared later rooted plants and have more time to initiate flower buds before digging. The difference in fruit number between crown treatments suggests that the increase in yield among plants with larger crowns may be related to a higher number of flowers initiated and developed in larger crowns (Table 4).

According to our results from two growing seasons, initial crown diameter of bare-root transplants should be a key consideration for strawberry production. The effect of initial crown diameter was consistent for the three major cultivars in Florida and has a strong effect on early and total yield of strawberries. Though it is not current practice for nurseries to grade according to a crown size, nurseries could offer larger crowns at a price premium to growers in the future. Our data suggests that a 10 -mm minimum diameter could be a good starting point. Taking into account historical weekly price data for Florida fresh fruit (USDA, 2014b) over the last 10 season, and simply multiplying by weekly yields from our experiments, shifting to crowns with diameter $>10 \mathrm{~mm}$ vs. those $<10 \mathrm{~mm}$ could represent a difference in gross revenue of up to $\$ 21,813 /$ ha for a 20-week harvest period. A nuanced economic analysis is beyond the scope of the present study, especially as there is no information on what price premium would be required for nurseries to provide larger crown sizes. However, the difference in gross revenue alone suggests that growers might benefit from paying a premium for uniformly large crown sizes of 'Strawberry Festival', 'Florida Radiance', and WinterStar ${ }^{\mathrm{TM}}$.

\section{Literature cited}

Bish, E.B. and D.J. Cantliffe. 2002. Temperature conditioning and container size affect early season fruit yield of strawberry plug plants in a winter, annual hill production system. HortScience 37:762764.

Bish, E.B. and D.J. Cantliffe. 2003. Plantlet size affects growth and development of strawberry plug transplants. Proc. Florida State Hort. Soc. 116:105-107.

Bish, E.B., D.J. Cantliffe, and C.K. Chandler. 2000. Strawberry daughter plant size alters transplant growth and development. Acta Hort. 533:121-125.

Bish, E.B., D.J. Cantliffe, and C.K. Chandler. 2002. Temperature conditioning and container size affect early season fruit yield of strawberry plug plants in a winter, annual hill production system. HortScience 37:762-764.

Cocco, C., J.L. Andriolo, F.L. Cardoso, L. Erpen, and O.J. Schmitt. 2011. Crown size and transplant type on the strawberry yield. Scientia Agricola 68:489-493.

Darnell, R.L. and G.C. Martin. 1988. Role of assimilate translocation and carbohydrate accumulation in fruit set of strawberry. J. Amer. Soc. Hort. Sci. 113:114-118.

Florida Automated Weather Network. 2014. Report Generator for Balm. 6 Jan. 2015. <http://fawn.ifas.ufl.edu/data/ reports $/>$.

Gilreath, J.P., B.M. Santos, J.W. Noling, S.J. Locascio, D.W. Dickson, E.N. Rosskopf, and S.M. Olson. 2006. Performance of containerized and bare-root 
transplants with soil fumigants for Florida strawberry production. HortTechnology 16:461-465.

Hochmuth, G., D. Cantliffe, C. Chandler, C. Stanley, E. Bish, E. Waldo, D. Legard, and J. Duval. 2006. Containerized strawberry transplants reduce establishment period, water use and enhance early growth and flowering compared with bare-root plants. HortTechnology 16:46-54.

Hokanson, S.C., F. Takeda, J.M. Enns, and B.L. Black. 2004. Influence of plant storage duration on strawberry runner tip viability and field performance. HortScience 39:1596-1600.

Jarvis, W.R. 1962. The dispersal of spores of Botrytis cinerea fr. in a raspberry plantation. Trans. Br. Mycol. Soc. 45:549559.

Johnson, C., T. Raiford, and K. Whitley. 2008. Initial crown diameter of transplants influences marketable yield components of two strawberry cultivars in annual hill production system. Intl. J. Fruit Sci. 5 (4):23-29.

Macias-Rodriguez, L., E. Quero, and M. G. Lopez. 2002. Carbohydrate differences in strawberry crowns and fruit (Fragaria $\times$ ananassa) during plant development. J. Agr. Food Chem. 50:33173321 .

Menzel, C.M. and L. Smith. 2011. Effect of time of planting, plant size, and nursery-growing environment on the performance of 'Festival' strawberry in a subtropical environment. HortTechnology 21:56-66.
Menzel, C.M. and L. Smith. 2012. Effect of time of planting and plant size on the productivity of 'Festival' and 'Florida Fortuna' strawberry plants in a subtropical environment. HortTechnology 22:330 337.

Mossler, M. 2010. Florida crop/pest management profiles: Strawberries. Inst. Food Agr. Sci. Univ. Florida. CIR 1239. 5 Aug. 2013. <http://edis.ifas.ufl.edu/ pi037>.

Santos, B.M., N.A. Peres, J.F. Price, V.M. Whitaker, P.J. Dittmar, S.M. Olson, and S.A. Smith. 2013. Strawberry production in Florida, p. 281-291. In: S.M. Olson and B.M. Santos (eds.). Vegetable production handbook for Florida 20122013. Inst. Food Agr. Sci. Univ. Gainesville, FL.

Simonne, E.H. and M.D. Dukes. 2009. Principles and practices of irrigation management for vegetables, p. 17-23. In: S.M. Olson and E.H. Simonne (eds.). Vegetable production handbook for Florida 2009-2010. Vance Publ., Lenexa, KS.

Stapleton, S.C., C.K. Chandler, D.E. Legard, J.F. Price, and J.C. Sumler. 2001. Transplant source affects fruiting performance and pest of 'Sweet Charlie' strawberry in Florida. HortTechnology 11:61-65.

Tanino, K.K. and R. Wang. 2008. Modeling chilling requirement and diurnal temperature differences on flowering and yield performance in strawberry crown production. HortScience 43:2060-2065.
U.S. Department of Agriculture. 2012. Table 6-U.S. strawberry prices received by growers, major States, by use, 1970-2012. 7 Jan. 2015. <http://usda.mannlib.cornell.edu/MannUsda/viewDocumentInfo. do?documentID $=1381>$.

U.S. Department of Agriculture. 2014a. Central Florida strawberry report. 17 Feb. 2015. <http://quickstats.nass.usda.gov/ results /D 5E4F6AD-8CDA-356FB9B5-86EC573676E7>.

U.S. Department of Agriculture. 2014b. 2013 State agricultural review. 30 June 2014. <http://www.nass.usda.gov/ QuickStats/AgOverview/stateOverview. php? state $=$ FLORIDA $>$.

Whitaker, V.M., T. Hasing, and C.K. Chandler. 2011. Historical trends in strawberry fruit quality revealed by a trial of University of Florida cultivars and advanced selection. HortScience 46: 553-557.

Wu, F., Z. Guan, and A. Whidden. 2012. Strawberry industry overview and outlook. 5 Aug. 2013. <http://www.fred. ifas.ufl.edu/pdf/webinar/Strawberry. pdf>.

Yang, X., L.L. Wilson, L.V. Maddon, and M.A. Ellis. 1990. Rain splash dispersal of Collectotrichum acutatum from infected strawberry fruit. Phytopathology 80:590595. 